Удк 547.458.84:54.058:547-39

\title{
ПОЛУЧЕНИЕ МИКРОКРИСТАЛЛИЧЕСКОЙ ЦЕЛЛЮЛОЗЫ НЕПОСРЕДСТВЕННО ИЗ ДРЕВЕСИНЫ ПОД ВОЗДЕЙСТВИЕМ МИКРОВОЛНОВОГО ИЗЛУЧЕНИЯ
}

\author{
() Е.Ю. Куинир", С.А. Аутлов, Н.Г. Базарнова \\ Алтайский государственный университет, пр. Ленина, 61, Барнаул, 656049 \\ (Россия), e-mail: eugenekuschnier@gmail.com
}

Исследовано влияние состава растворов надуксусной кислоты на изменение характеристик целлюлозы при окислительно-гидролитической обработке древесины осины и сосны под воздействием микроволнового излучения. Образцы полученной целлюлозы охарактеризованы методами вискозиметрии, рентгеновской дифракции и ИКспектроскопии. Установлено, что в кислых средах при начальных концентрациях надуксусной кислоты не более $15 \%$ и пероксида водорода не более 3 моль/дм³ главным фактором, определяющим скорость деструкции целлюлозы до «предельной» степени полимеризации, является концентрация серной кислоты. При концентрации серной кислоты 0,06 моль/дм ${ }^{3}$ и увеличении продолжительности окислительно-гидролитической обработки древесины сосны от 1 до 2 ч выявлено разупорядочивающее влияние микроволнового излучения на кристаллиты получаемой из нее целлюлозы. Показано, что в условиях микроволнового нагрева при продолжительности процесса 1,5-2 ч и концентрации серной кислоты $0,3-0,7$ моль/дм ${ }^{3}$ характеристики продуктов окислительно-гидролитической обработки древесины осины и сосны 15\%-ной надуксусной кислотой соответствуют частично окисленной микрокристаллической целлюлозе.

Ключевые слова: древесина осины, древесина сосны, надуксусная кислота, окислительно-гидролитическая деструкция, микроволновое излучение, микрокристаллическая целлюлоза.

\section{Введение}

Микрокристаллическая целлюлоза (МКЦ) представляет собой материал, состоящий из наиболее упорядоченных элементов надмолекулярной структуры целлюлозы, остающихся после ее химической деструкции до «предельной» степени полимеризации. На протяжении многих лет она широко и успешно применяется в фармацевтической, пищевой, косметической и других промышленных отраслях [1]. Общепринятые технологии получения высококачественной МКЦ основаны на использовании дорогого сырья очищенной хлопковой и древесной целлюлозы [2, 3]. Поэтому одной из главных задач исследований, направленных на разработку способов получения МКЦ, в настоящее время является поиск условий химической деструкции дешевого сырья, обеспечивающих эффективное отделение кристаллической части целлюлозы от сопутствующих ей компонентов.

В результате многочисленных исследований, проведенных научными коллективами разных стран, для

Кушнир Евгений Юрьевич - аспирант кафедры органической химии, тел.: (3852) 36-95-37,

e-mail: eugenekuschnier@gmail.com

Аутлов Станислав Артурович - старший

преподаватель кафедры органической химии, кандидат химических наук, тел.: (3852) 36-95-37,

e-mail: maxtanly@gmail.com

Базарнова Наталья Григорьевна - заведующая кафедрой органической химии, профессор, доктор химических наук, тел.: (3852) 36-95-37,

e-mail: bazarnova@chem.asu.ru получения МКЦ было предложено использовать бактериальную целлюлозу [4, 5], туницин оболочников [6], целлюлозу для производства бумаги [7], небеленую целлюлозу $[8,9]$, древесное сырье и солому [10, 11], другие отходы переработки сельскохозяйственных и технических культур [12-17]. В зависимости от вида целлюлозосодержащего сырья предложено применение различных методов его деструкции: кислотного [4] и ферментативного [18] гидролиза, взрывного автогидролиза [10], окисления в кислой $[9,11]$ и ще-

\footnotetext{
* Автор, с которым следует вести переписку.
} 
лочной [19] средах. Для повышения эффективности дезинтеграции волокнистой структуры целлюлозы предложено использование добавок недериватизирующих органических соединений, препятствующих рекристаллизации неупорядоченных участков элементарных фибрилл [20]. Показано положительное влияние на процессы получения МКЦ физических воздействий: механической активации [21], ультразвукового диспергирования [22] и облучения электромагнитными волнами диапазона сверхвысоких частот [23].

Несмотря на огромное практическое значение результатов проведенных исследований, большинство предпринятых попыток использования дешевого целлюлозосодержащего сырья не получило положительной оценки в связи с присущими им недостатками, основными из которых являются многостадийность химической обработки и проблема получения очищенного продукта. Одно из наиболее удачных и перспективных направлений исследований заключается в поиске условий получения МКЦ путем окислительной и окислительно-гидролитической деструкции лигноцеллюлозного сырья с применением таких эффективных делигнифицирующих агентов, как озон, пероксид водорода и пероксикислоты. Примерами работ в данной области являются исследования по получению МКЦ из древесного и травянистого сырья, проведенные сотрудниками ИХ Коми НЦ УрО РАН $[11,24]$, ИХХТ СО РАН и СибГТУ [21, 25-27]. Важным преимуществом применения окислительных и окислительно-гидролитических методов является возможность совмещенного протекания процессов деструкции лигнина и целлюлозы, позволяющего уменьшить число стадий и продолжительность химической обработки сырья при получении МКЦ.

В настоящей работе с целью подбора условий одностадийного получения МКЦ исследовано влияние состава растворов надуксусной кислоты (НУК) на изменение характеристик целлюлозы при окислительно-гидролитической обработке древесины под воздействием микроволнового излучения (МВИ).

\section{Экспериментальная часть}

В качестве лигноцеллюлозного сырья для получения МКЦ использовали измельченную древесину осины (Populus tremula L.) и сосны (Pinus sylvestris L.) в виде опилок с размерами 0,315-0,630 мм. Влажность древесных опилок составляла 5,0\%. Содержание структурных компонентов в измельченной древесине (табл. 1) определяли по стандартным методикам [28]. НУК получали ацетилированием пероксида водорода уксусной кислотой в присутствии каталитических количеств серной кислоты [29]. Для получения МКЦ использовали 15\%-ные растворы НУК с содержанием пероксида водорода 3 моль/дм лоты 4 моль/дм ${ }^{3}$ и серной кислоты 0,06-0,7 моль/дм³ . Древесные опилки обрабатывали растворами НУК под воздействием МВИ с частотой 2450 МГц и мощностью 700 Вт при жидкостном модуле 50 и продолжительности 1-2 ч. По окончании обработки остаток отделяли фильтрованием и промывали горячей (70$\left.80{ }^{\circ} \mathrm{C}\right)$ дистиллированной водой. Для оценки влияния МВИ на процесс получения МКЦ аналогичный эксперимент проводили с применением конвекционного нагрева при $100{ }^{\circ} \mathrm{C}$.

Среднюю степень полимеризации $\left(\mathrm{C \Pi}_{\mathrm{cp}}\right)$ полученных продуктов определяли вискозиметрическим методом в кадоксене (ГОСТ 25438-82). ИК-спектры образцов целлюлозы регистрировали на Фурьеспектрометре Инфралюм ФТ-801, рентгенограммы - на дифрактометре Shimadzu XRD 6000 (Национальный исследовательский Томский политехнический университет). Степень кристалличности целлюлозы (CK) рассчитывали по интегральной интенсивности рассеяния рентгеновских лучей как отношение суммы площадей дифракционных максимумов к общей площади под кривой рассеяния за вычетом рассеяния фона [30]. Поперечные размеры кристаллитов целлюлозы в направлении нормали к системе плоскостей (020) рассчитывали по формуле Дебая - Шеррера

$$
B_{020}=\frac{k \times \lambda}{h \times \cos \theta_{020}}
$$

где $k=0,9$ - безразмерный форм-фактор; $\lambda$ - длина волны $\mathrm{CuK}_{\alpha}$-излучения $(0,15418$ нм $) ; h$ - полуширина рефлекса 020, рад; $\theta_{020}$ - угол дифракции от системы плоскостей (020).

Таблица 1. Содержание основных компонентов в исходной древесине (\% от абсолютно сухой древесины)

\begin{tabular}{c|c|c|c}
\hline Порода древесины & Целлюлоза & Лигнин & Гемицеллюлозы \\
\hline Осина & 48,1 & 21,8 & 26,4 \\
Сосна & 49,6 & 28,0 & 16,5 \\
\hline
\end{tabular}




\section{Обсуждение результатов}

Расход НУК (концентрация раствора - 15\%, жидкостный модуль - 50) в эксперименте по получению МКЦ соответствовал условиям, обеспечивающим эффективное удаление лигнина из древесины [31]. Для подбора условий получения МКЦ под воздействием МВИ исследовали влияние продолжительности окислительно-гидролитической обработки древесины и состава используемых растворов НУК на характеристики выделяемой целлюлозы.

В таблице 2 представлены характеристики образцов целлюлозы в зависимости от продолжительности выделения 15\%-ной НУК под воздействием МВИ при концентрации $\mathrm{H}_{2} \mathrm{SO}_{4}$ 0,06 моль/дм ${ }^{3}$ (соответствует количеству $\mathrm{H}_{2} \mathrm{SO}_{4}$, введенному в смесь $\mathrm{H}_{2} \mathrm{O}_{2}$ и $\mathrm{CH}_{3} \mathrm{COOH}$ при приготовлении НУК). Для сравнения также приведены характеристики целлюлозы, выделенной из древесины этим же раствором НУК, но с применением конвекционного нагрева при $100{ }^{\circ} \mathrm{C}$. При одинаковой продолжительности процесса (2 ч) образцы целлюлозы, полученные под воздействием МВИ, характеризуются меньшими значениями выхода и СП ср, чем при использовании конвекционного нагрева. Это свидетельствует об интенсифицирующем влиянии МВИ на процессы окислительно-гидролитической деструкции полисахаридов компонентами раствора НУК и согласуется с данными, полученными нами ранее [32, 33].

За 1 ч обработки древесины раствором НУК под воздействием МВИ происходит практически такое же уменьшение выхода и СП ср целлюлозы как за 2 ч обработки с применением конвекционного нагрева. Однако при этом выход полученных продуктов не достигает содержания целлюлозы в исходной древесине (табл. 1), что связано с неполным удалением гемицеллюлоз. Очевидно, при концентрации $\mathrm{H}_{2} \mathrm{SO}_{4}$ 0,06 моль/дм ${ }^{3}$ воздействие МВИ интенсифицирует главным образом процессы деструкции лигноуглеводной матрицы и аморфных областей целлюлозы, не оказывая существенного влияния на участки элементарных фибрилл с более упорядоченной организацией макромолекул. В пользу этого предположения свиде-

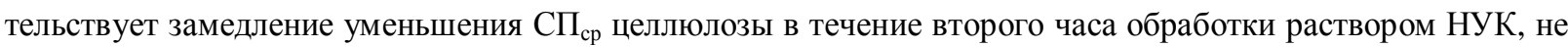
позволяющее достичь «предельных» значений, характерных для древесной МКЦ (120-280, согласно [34]). Для двух древесных пород СП ср целлюлозы уменьшается всего на 160 единиц и становится равной 400 .

Несмотря на неполное разрушение участков элементарных фибрилл целлюлозы с переходным упорядочением макромолекул при концентрации $\mathrm{H}_{2} \mathrm{SO}_{4}$ 0,06 моль/дм и продолжительности выделения 2 ч, образцы, полученные с использованием микроволнового и конвекционного нагрева, характеризуются достаточно высокими значениями СК, соответствующими диапазону для МКЦ (0,63-0,83 согласно [35]). Этот факт обусловлен высоким содержанием кристаллической части целлюлозы в составе исходной древесины, на что указывают значения СК и содержания альфа-целлюлозы для образцов холоцеллюлозы (табл. 3), выделенных по стандартной методике [28]. Однако в отличие от холоцеллюлозы из исходной древесины образцы целлюлозы, полученные при продолжительности выделения 2 ч, характеризуются несколько бо́льшими значениями поперечных размеров кристаллитов. Это свидетельствует о некотором упорядочении элементарных фибрилл в поперечном направлении, которое согласно представлениям, рассмотренным в работах [36, 37], может быть вызвано переходом целлюлозы в высокоэластическое состояние в процессе набухания и ее последующей рекристаллизацией.

Таблица 2. Характеристики целлюлозы в зависимости от продолжительности выделения 15\%-ной НУК (концентрация $\mathrm{H}_{2} \mathrm{SO}_{4}-0,06$ моль/дм³ ${ }^{3}$ )

\begin{tabular}{c|c|c|c|c|c|c|c|c}
\hline Продолжительность & \multicolumn{4}{|c|}{ Древесина осины } & \multicolumn{4}{c}{ Древесина сосны } \\
\cline { 2 - 9 } выделения, ч & Выход, \% & СП $_{\text {ср }}$ & СК & $B_{020}$, нм & Выход, \% & СП ср $_{\text {ск }}$ & $B_{020}$, нм \\
\hline 1 & 51,0 & 560 & 0,62 & 2,5 & 51,2 & 560 & 0,67 & 2,5 \\
1,5 & 49,4 & 440 & 0,64 & 2,7 & 48,6 & 480 & 0,65 & 2,6 \\
2 & 47,2 & 400 & 0,68 & 2,9 & 47,5 & 400 & 0,63 & 2,5 \\
& $(52,8)^{*}$ & $(540)^{*}$ & $(0,67)^{*}$ & $(2,8)^{*}$ & $(51,5)^{*}$ & $(520)^{*}$ & $(0,66)^{*}$ & $(3,2)^{*}$ \\
\hline
\end{tabular}

* - характеристики целлюлозы, выделенной с использованием конвекционного нагрева $\left(100^{\circ} \mathrm{C}\right)$.

Таблица 3. Характеристики холоцеллюлозы, выделенной 10\%-ной НУК

\begin{tabular}{c|c|c|c|c|c}
\hline \multirow{2}{*}{$\begin{array}{c}\text { Порода } \\
\text { древесины }\end{array}$} & \multirow{2}{*}{ Выход, \% } & \multicolumn{2}{|c|}{ Содержание альфа-целлюлозы } & \multirow{2}{*}{ СК } & \multirow{2}{*}{$B_{020}$, нм } \\
\cline { 3 - 4 } & & $\%^{1}$ & $\%^{2}$ & 0,64 & 2,4 \\
Осина & 69,1 & 68,6 & 98,6 & 0,64 & 2,2 \\
Сосна & 66,0 & 64,4 & 85,7 &
\end{tabular}

Примечания: 1 - от абсолютно сухой холоцеллюлозы; 2 - в пересчете на целлюлозу в абсолютно сухой древесине. 
В условиях микроволнового нагрева увеличение продолжительности выделения от 1 до 2 ч для образцов деструктированной целлюлозы, полученных из древесины осины, сопровождается увеличением СК и поперечных размеров кристаллитов (табл. 2). Для образцов целлюлозы, полученных из древесины сосны, увеличение продолжительности выделения под воздействием МВИ, наоборот, приводит к уменьшению СК, поперечные размеры кристаллитов при этом остаются практически неизменными. Однако при проведении процесса с применением конвекционного нагрева при $100{ }^{\circ} \mathrm{C}$ (т.е. в менее жестких условиях) эти особенности структурных изменений целлюлозы при выделении из древесины сосны не проявляются, о чем свидетельствуют более высокие значения СК и поперечных размеров кристаллитов по сравнению с использованием микроволнового нагрева. Очевидно, в условиях обработки древесины раствором НУК под воздействием МВИ разрушение некристаллических участков элементарных фибрилл целлюлозы сопровождается частичной декристаллизацией упорядоченных областей и образованием дефектов на их поверхности.

Различный характер изменений структурных характеристик образцов целлюлозы при выделении из древесины осины и сосны под воздействием МВИ, вероятно, связан с особенностями надмолекулярной организации полисахаридов и их устойчивости к окислительно-гидролитической деструкции в составе исходной древесины. Сравнение значений СК образцов целлюлозы, полученных из древесины осины и сосны при продолжительности выделения 1 ч (табл. 2), позволяет предположить, что в условиях воздействия МВИ мезоморфные и паракристаллические области целлюлозы древесины сосны отличаются меньшей устойчивостью к деструктирующему действию компонентов раствора НУК. Обработка древесины сосны раствором НУК под воздействием МВИ в течение 1 ч приводит к достаточно заметному уменьшению содержания некристаллических областей в получаемой целлюлозе и достижению максимального значения СК $(0,67)$. При увеличении продолжительности выделения целлюлозы из древесины сосны от 1 до 2 ч начинает проявляться влияние реакционной среды и МВИ на макромолекулы вблизи поверхности кристаллитов, препятствующее их упорядочению в поперечном направлении и сопровождающееся снижением СК целлюлозы. Отсутствие подобных эффектов при выделении целлюлозы из древесины осины может быть объяснено более медленным разрушением мезоморфных и паракристаллических участков элементарных фибрилл и, как следствие, меньшей доступностью макромолекул целлюлозы вблизи поверхности кристаллитов для специфического влияния реакционной среды и МВИ.

Увеличение концентрации $\mathrm{H}_{2} \mathrm{SO}_{4}$ в $15 \%$-ном растворе НУК до 0,3 моль/дм ${ }^{3}$ и выше приводит к более интенсивному протеканию деструкции целлюлозы в условиях микроволнового нагрева (табл. 4). При одинаковой продолжительности выделения (1,5 ч) образцы целлюлозы, полученные в результате обработки древесины растворами НУК с более высокой концентрацией $\mathrm{H}_{2} \mathrm{SO}_{4}$, характеризуются меньшими значениями выхода, $\mathrm{CП}_{\text {ср }}$ и поперечных размеров кристаллитов, чем при содержании $\mathrm{H}_{2} \mathrm{SO}_{4}$ 0,06 моль/дм ${ }^{3}$. Кроме того, для образцов целлюлозы, полученных при концентрации $\mathrm{H}_{2} \mathrm{SO}_{4} 0,3-0,7$ моль/дм ${ }^{3}$, в целом характерны более высокие значения СК. На рентгенограммах полученных продуктов (рис. 1) имеются два сильно перекрывающихся дифракционных максимума в области $2 \theta=15-16^{\circ}$, соответствующие рефлексам $1 \overline{1} 0$ и 110 кристаллической решетки целлюлозы І. Изменение содержания $\mathrm{H}_{2} \mathrm{SO}_{4}$ в растворе НУК от 0,3 до 0,7 моль/дм ${ }^{3}$ в условиях микроволнового нагрева приводит к получению образцов целлюлозы с различной степенью деструкции макромолекул, что выражается в уменьшении значений $\mathrm{CП}_{\mathrm{cp}}$, но в границах интервала, характерного для «предельной» СП древесной целлюлозы. Таким образом, при концентрации $\mathrm{H}_{2} \mathrm{SO}_{4}$ в растворе НУК 0,30,7 моль/дм ${ }^{3}$ и продолжительности выделения под воздействием МВИ 1,5 ч характеристики продуктов соответствуют порошковой целлюлозе, получаемой путем гетерогенного кислотного гидролиза.

Концентрация $\mathrm{H}_{2} \mathrm{SO}_{4}$ в $15 \%$-ном растворе НУК от 0,3 моль/дм ${ }^{3}$ и выше обеспечивает получение образцов МКЦ, характеризующихся меньшими значениями поперечных размеров кристаллитов, чем целлюлоза, выделенная из древесины при той же продолжительности процесса и содержании $\mathrm{H}_{2} \mathrm{SO}_{4}$ 0,06 моль/дм ${ }^{3}$ (табл. 2). Наряду с более высокими значениями СК образцов МКЦ отмеченная особенность протекания процесса свидетельствует о том, что при увеличении концентрации $\mathrm{H}_{2} \mathrm{SO}_{4}$ в условиях воздействия МВИ происходит ускорение гидролитической деструкции макромолекул целлюлозы в мезоморфных и паракристаллических участках элементарных фибрилл и, как следствие, уменышение возможности их рекристаллизации с образованием дефектных кристаллических структур. В то же время при одинаковой продолжительности выделения МКЦ под воздействием МВИ увеличение концентрации $\mathrm{H}_{2} \mathrm{SO}_{4}$ в растворе НУК в пределах 0,30,7 моль/дм ${ }^{3}$ не сопровождается уменьшением поперечных размеров кристаллитов, что указывает на интенсификацию деструкции макромолекулярных цепей преимущественно в продольном направлении кристаллитов (т.е. с торцов). При этом отсутствует строгая зависимость между изменением значений выхода и СК образцов МКЦ при увеличении концентрации $\mathrm{H}_{2} \mathrm{SO}_{4}$. Подобное отсутствие корреляции между количеством удаляемого материала и изменением значений СК при гидролизе древесной целлюлозы отмечено авторами работы [38] и по их мнению связано с деструкцией самих кристаллитов. 
Таблица 4. Характеристики целлюлозы в зависимости от концентрации $\mathrm{H}_{2} \mathrm{SO}_{4}$ в растворе НУК (продолжительность выделения - 1,5 ч)

\begin{tabular}{|c|c|c|c|c|c|c|c|c|}
\hline \multirow{2}{*}{$\begin{array}{c}\text { Концентрация } \\
\mathrm{H}_{2} \mathrm{SO}_{4}, \text { моль/дм }\end{array}$} & \multicolumn{4}{|c|}{ Древесина осины } & \multicolumn{4}{|c|}{ Древесина сосны } \\
\hline & Выход, \% & $\mathrm{C} \Pi_{\mathrm{cp}}$ & $\mathrm{CK}$ & $B_{020}, \mathrm{HM}$ & Выход, \% & $\mathrm{C} \Pi_{\mathrm{cp}}$ & $\mathrm{CK}$ & $B_{020}, \mathrm{HM}$ \\
\hline 0,3 & 45,2 & 260 & 0,64 & 2,2 & 42,7 & 300 & 0,67 & 2,3 \\
\hline 0,5 & 42,2 & 200 & 0,69 & 2,2 & 42,2 & 260 & 0,65 & 2,3 \\
\hline 0,7 & 37,9 & 120 & 0,67 & 2,2 & 37,9 & 160 & 0,71 & 2,3 \\
\hline
\end{tabular}

Рис. 1. Рентгенограммы МКЦ, выделенной из древесины осины (1) и сосны (2) (концентрация $\mathrm{H}_{2} \mathrm{SO}_{4}-0,3$ моль/дм продолжительность выделения - 1,5 ч)

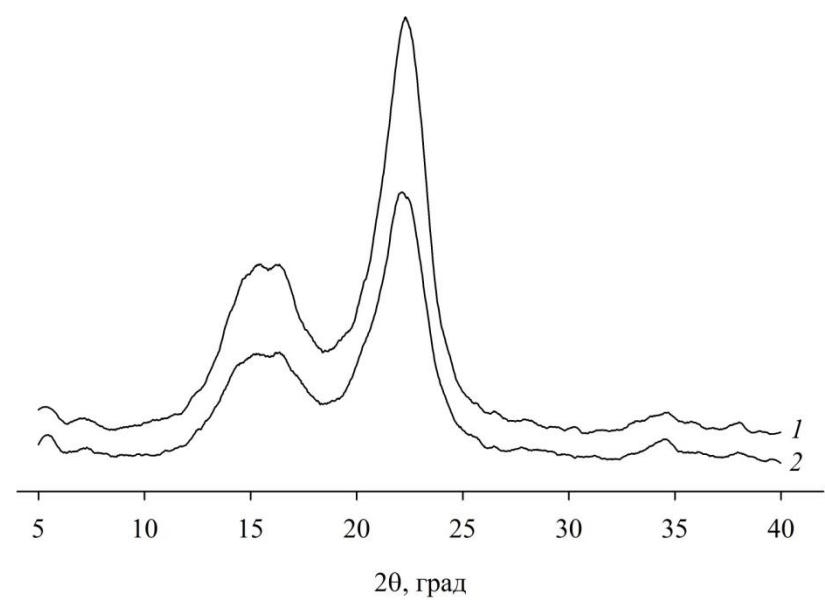

Данные, полученные в результате обработки древесины 15\%-ным раствором НУК при содержании $\mathrm{H}_{2} \mathrm{SO}_{4}$ 0,3-0,7 моль/дм³ упорядоченных областей целлюлозы в условиях микроволнового нагрева. При концентрации $\mathrm{H}_{2} \mathrm{SO}_{4}$ в растворе НУК 0,06 моль/дм³ уменьшение СК целлюлозы в течение второго часа выделения из древесины сосны (табл. 2) достаточно убедительно объясняется частичным разупорядочением кристаллитов. Увеличение концентрации $\mathrm{H}_{2} \mathrm{SO}_{4}$ в растворе НУК до 0,3-0,7 моль/дм ${ }^{3}$ приводит к более интенсивному разрушению некристаллических надмолекулярных образований, препятствуя их накоплению и обеспечивая высокие значения СК получаемых продуктов. Стабильность поперечных размеров кристаллитов при значительном снижении значений СП ср образцов МКЦ, вызванном увеличением концентрации гидролизующего агента, указывает на протекание процесса декристаллизации преимущественно в продольном направлении кристаллитов, начиная с торцов. Очевидно, в первую очередь это связано с различной устойчивостью связей, фиксирующих положения глюкопиранозных звеньев, по трем направлениям кристаллической решетки. В пользу предположения о частичном разупорядочении кристаллитов также свидетельствует увеличение содержания в целлюлозе легкогидролизуемой фракции при воздействии МВИ, установленное авторами работы [39].

В ИК-спектрах полученных образцов МКЦ (рис. 2) отсутствуют характеристические полосы поглощения фенилпропановых единиц лигнина (1605-1593, 1515-1495 и 1470-1460 см-1). Это свидетельствует о протекании глубоких окислительных превращений фенольных структур и эффективной диффузии продуктов делигнификации в раствор в условиях проведенного эксперимента. Положение, форма и соотношение интенсивностей полос в ИК-спектрах образцов МКЦ аналогичны описанному в [40] спектру древесной целлюлозы, выделенной по методу Кюршнера - Хоффера. Характер поглощения в области 1400-1300 см-1 обусловлен структурными особенностями полученных образцов МКЦ. В отличие от спектров негидролизованных остатков хлопковой и древесной целлюлозы, описанных в [41], спектры выделенных образцов МКЦ характеризуются отсутствием полосы при $1360 \mathrm{~cm}^{-1}$, а также меньшей интенсивностью и перекрыванием полос при 1340 и $1320 \mathrm{~cm}^{-1}$. Наличие полосы при $1731 \mathrm{~cm}^{-1}$, соответствующей валентным колебаниям карбонильной группы, наряду с указанными особенностями, дает основание предполагать о частичном

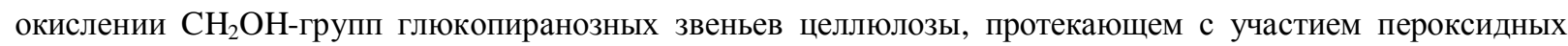
соединений. Как показано при получении МКЦ окислительно-гидролитическим способом [42], поглощение в области $1730 \mathrm{~cm}^{-1}$ появляется в результате модифицирования поверхности кристаллитов карбоксильными группами. 


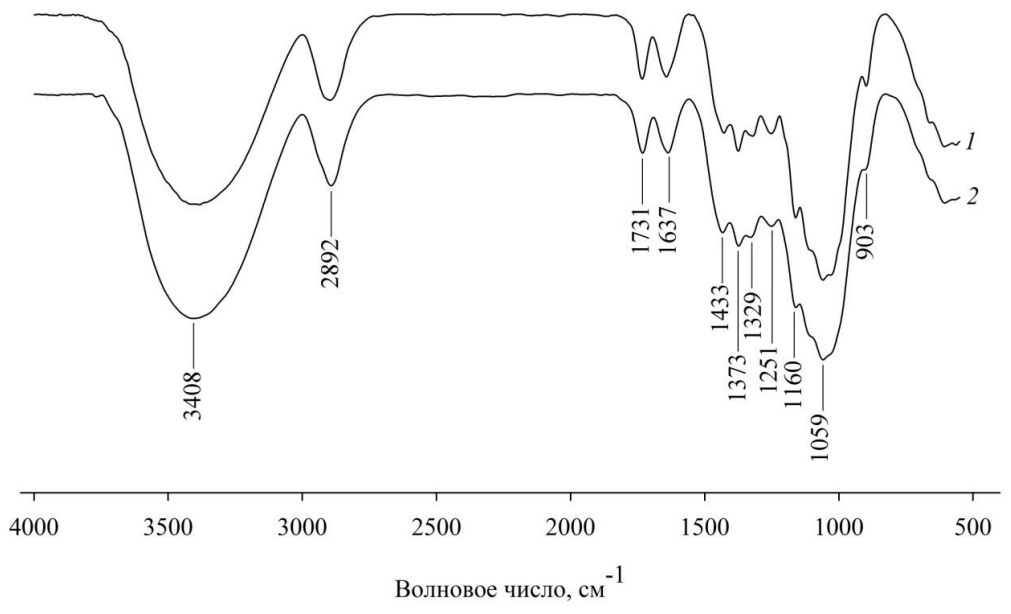

Рис. 2. ИК-спектры МКЦ, выделенной из древесины осины (1) и сосны (2) (концентрация $\mathrm{H}_{2} \mathrm{SO}_{4}-$ 0,3 моль/дм ${ }^{3}$, продолжительность выделения - 1,5 ч)

Анализ полученных результатов позволяет сделать заключение о том, что в условиях проведенного эксперимента главным фактором, определяющим скорость снижения СП ср целлюлозы до «предельных» значений, является концентрация $\mathrm{H}_{2} \mathrm{SO}_{4}$. Это свидетельствует о преобладающей роли гидролитической деструкции над окислительной в процессе разрушения паракристаллических участков элементарных фибрилл целлюлозы при обработке древесины $15 \%$-ной НУК под воздействием МВИ. Согласно существующим представлениям [43-45] в кислой среде основным направлением окислительных превращений с участием НУК и $\mathrm{H}_{2} \mathrm{O}_{2}$ является процесс делигнификации, а деструкция полисахаридов обусловлена протеканием побочного процесса - гомолитического разложения пероксидных связей. Даже при достаточно высоких начальных концентрациях НУК (15\%) и $\mathrm{H}_{2} \mathrm{O}_{2}$ (3 моль/дм $\left.{ }^{3}\right)$ окислительно-гидролитическая обработка древесины под воздействием МВИ в течение 2 ч не приводит к снижению СП ср целлюлозы до «предельных» значений. Очевидно, наибольший вклад окислительные превращения целлюлозы вносят в разрушение аморфных участков элементарных фибрилл. По мере уменьшения концентрации пероксидных соединений роль превращений с их уча-

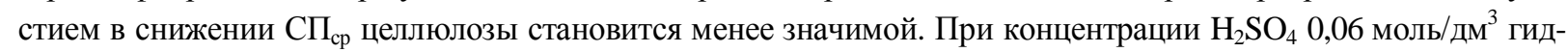
ролитическая деструкция целлюлозы под воздействием МВИ протекает недостаточно интенсивно, чтобы обеспечить быстрое разрушение мезоморфных и паракристаллических участков элементарных фибрилл. Получение МКЦ из древесины при продолжительности процесса 1,5-2 ч становится возможным лишь в результате увеличения концентрации $\mathrm{H}_{2} \mathrm{SO}_{4}$ в $15 \%$-ном растворе НУК до 0,3-0,7 моль/дм

\section{Выводы}

1. В кислых средах при начальных концентрациях НУК не более $15 \%$ и $\mathrm{H}_{2} \mathrm{O}_{2}$ не более 3 моль/дм ${ }^{3}$ окислительные превращения структурных компонентов древесины под воздействием МВИ не оказывают решающего влияния на разрушение паракристаллических участков элементарных фибрилл целлюлозы.

2. В относительно мягких условиях гидролитической деструкции (концентрация $\mathrm{H}_{2} \mathrm{SO}_{4}$ 0,06 моль/дм ${ }^{3}$ ) выявлено разупорядочивающее влияние МВИ на кристаллиты целлюлозы при увеличении продолжительности ее выделения из древесины сосны 15\%-ным раствором НУК от 1 до 2 ч.

3. Предложены условия одностадийного получения частично окисленной МКЦ путем окислительногидролитической обработки древесины под воздействием МВИ: концентрация НУК - 15\%, концентрация $\mathrm{H}_{2} \mathrm{SO}_{4}-0,3-0,7$ моль/дм ${ }^{3}$, жидкостный модуль - 50, продолжительность процесса - 1,5-2 ч.

\section{Список литературы}

1. Battista O.A., Smith P.A. Microcrystalline cellulose // Industrial and Engineering Chemistry. 1962. Vol. 54, N9. Pp. 20-29.

2. $\quad$ Patent 2978446 (US). Level-off D.P. cellulose products / O.A. Battista, P.A. Smith. 1961.

3. Patent 2313261 (CA). Process for preparing a high purity chemical-free microcrystalline cellulose from a chemically produced cellulose / P. Jollez, E. Chornet. 1999.

4. Patent 4745058 (US). Method for producing cellulosic fibers and microcrystalline cellulose / P.M. Townsley. 1988. 
5. Oliveira R.L. de, Barud H.S., Assunção R.M.N. de, Meireles C.S., Carvalho G.O., Filho R.G., Messaddeq Y., Ribeiro S.J.L. Synthesis and characterization of microcrystalline cellulose produced from bacterial cellulose // Journal of Thermal Analysis and Calorimetry. 2011. Vol. 106. N3. Pp. 703-709.

6. Patent $101914859(\mathrm{CN})$. Method for extracting microcrystalline cellulose from sea squirts and preparing lyotropic cholesteric crystal / P. Guangzhe, Z. Lihong, S. Guangjie, L. Jianrong, K. Tsunehisa. 2012.

7. Patent 7005514 (US). Process for preparing microcrystalline cellulose / X.T. Nguyen. 2006.

8. Patent 2377732 (CA). Treatment of pulp to produce microcrystalline cellulose / D. Schaible, B. Sherwood // 2001.

9. Казакова Е.Г., Демин В.А. Новый способ получения микрокристаллической целлюлозы // Журнал прикладной химии. 2009. Т. 82. Вып. 3. С. 502-505.

10. Patent 4645541 (US). Method of producing level off DP microcrystalline cellulose and glucose from lignocellulosic material / E.A. DeLong. 1987.

11. Кочева Л.С., Карманов А.П. Новые способы получения микрокристаллической целлюлозы // Химия и технология растительных веществ : материалы II Всероссийской конференции. Казань, 2002. С. 140.

12. Gaonkar S.M., Kulkarni P.R. Microcrystalline cellulose from coconut shells // Acta Polymerica. 1989. Vol. 40, N4. Pp. 292-293.

13. Ejikeme P.M. Investigation of the physicochemical properties of microcrystalline cellulose from agricultural wastes I: orange mesocarp // Cellulose. 2008. Vol. 15, N1. Pp. 141-147.

14. El-Sakhawy M., Hassan M.L. Physical and mechanical properties of microcrystalline cellulose prepared from agricultural residues // Carbohydrate Polymers. 2007. Vol. 67, N1. Pp. 1-10.

15. Mohamad Haafiz M.K., Eichhorn S.J., Hassan A., Jawaid M. Isolation and characterization of microcrystalline cellulose from oil palm biomass residue // Carbohydrate Polymers. 2013. Vol. 93, N2. Pp. 628-634.

16. Patent 102808347 (CN). Preparation method for microcrystalline cellulose / Du Junqi. 2012.

17. Patent $101413016(\mathrm{CN})$. Method for preparing microcrystalline cellulose and cellulose fuel ethanol by separating furfural residue / J. Jianxin, F. Yue, W. Kun, S. Runcang, S. Yadong, Z. Liwei. 2009.

18. Patent 5346589 (US). Crystalline cellulose production / E.L. Braunstein, R.L. Dostie, K.H. Germano, S.C. Lamb, C.S. Penet, P.B. Richards. 1994.

19. Patent 6392034 (US). Microcrystalline cellulose / S. Trusovs. 2002.

20. Patent 3388119 (US). Non-fibrous particulate cellulose and method of making same / M.M. Cruz Jr. 1968.

21. Кузнецова С.А., Кузнецов Б.Н., Александрова Н.Б., Данилов В.Г., Жижаев А.М. Получение арабиногалактана, дигидрокверцетина и микрокристаллической целлюлозы с использованием механохимической активации // Химия в интересах устойчивого развития. 2005. Т. 13, №2. С. 261-269.

22. Бармин М. И., Гребенкин А.Н., Бойко А.И., Иванова Е.Е., Картавых В.П., Кононеко В.П., Мельников В.В. Получение микрокристаллической целлюлозы из отходов льнопроизводства // Известия высших учебных заведений. Химия и химическая технология. 2004. Т. 47, вып. 3. С. 156-158.

23. Сарымсаков А.А., Балтаева М.М., Набиев Д.С., Рашидова С.Ш., Югай С.М. Диспергированная микрокристаллическая целлюлоза и гидрогели на ее основе // Химия растительного сырья. 2004. №2. С. 11-16.

24. Патент 2137779 (РФ). Способ получения порошковой целлюлозы / Б.Ф. Куковицкий, В.А. Демин. 1999.

25. Kuznetsov B.N., Kuznetsova S.A., Danilov V.G., Yatsenkova O.V., Petrov A.V. A green one-step process of obtaining microcrystalline cellulose by catalytic oxidation of wood // Reaction Kinetics, Mechanisms and Catalysis. 2011. Vol. 104, N2. Pp. 337-343.

26. Данилов В.Г., Яценкова О.В., Грязина Е.Ф., Кузнецов Б.Н. Изучение каталитической окислительной делигнификации автогидролизованной древесины осины // Новые достижения в химии и химической технологии растительного сырья : материалы V Всероссийской конференции. Барнаул, 2012.С. 83-85.

27. Вшивкова И.А., Каретникова Н.В., Пен Р.З., Бывшев А.В. Делигнификация пшеничной соломы пероксидом водорода с целью получения микрокристаллической целлюлозы // Новые достижения в химии и химической технологии растительного сырья : материалы V Всероссийской конференции. Барнаул, 2012.С. 79-80.

28. Шарков В.И., Куйбина Н.И., Соловьева Ю.П., Павлова Т.А. Количественный химический анализ растительного сырья. М., 1976. 72 с.

29. Кушнир Е.Ю., Аутлов С.А., Базарнова Н.Г. Приготовление надуксусной кислоты для делигнификации растительного сырья // «Мәңгілік ел» - Қазақстан білімі мен ғылымын жаңғыртудың уәждемесі» атты «Аманжолов окулары-2014»: Халық. ғыл.-тәжір. конф. материалдарының жинағы. 2-бөлім. Өскемен: С. Аманжолов атындағы ШҚМУ «Берел» баспасы, 2014. Б. 63-66.

30. Ястребинский А.А. Исследование надмолекулярной структуры целлюлозных материалов методом рентгеновской дифракции больших и малых углов // Методы исследования целюллозы / под ред. В.П. Карливана. Рига, 1981. C. 44-55.

31. Poljak A. Holzaufschluß mit Peressigsäure II. Cellulosebestimmung mit Peressigsäure // Holzforschung. 1951. Vol. 5, N2. Pp. 31-33.

32. Кушнир Е.Ю., Аутлов С.А. Влияние микроволнового излучения на процесс делигнификации древесины осины надуксусной кислотой // Труды молодых ученых Алтайского государственного университета : материалы XXXVI научной конференции. Барнаул, 2009. Вып. 6. С. 138-139.

33. Кушнир Е.Ю., Аутлов С.А., Базарнова Н.Г. Получение микрокристаллической целлюлозы из волокна льнакудряша под воздействием микроволнового излучения // Труды молодых ученых Алтайского государственного университета : материалы XXXIX научной конференции. Барнаул, 2012. Вып. 9. С. 153-154. 
34. Гальбрайх Л.С. Целлюлоза и ее производные // Соросовский образовательный журнал. 1996. №11. С. $47-53$.

35. Азаров В.И., Буров А.В., Оболенская А.В. Химия древесины и синтетических полимеров. СПб., 1999. 628 с.

36. Аким Э.Л. Реакционная способность и физическое состояние целлюлозы (обзор) // Химия древесины. 1984. №4. C. 3-17.

37. Филипп Б., Штеге Х.-Х. Влияние различных параметров реакции на гетерогенный гидролитический распад целлюлозы при получении микрокристаллического целлюлозного порошка // Химия древесины. 1976. №2. C. 3-9.

38. Петропавловский Г.А., Котельникова Н.Е. Микрокристаллическая целлюлоза (обзор) // Химия древесины. 1979. №6. С. 3-21.

39. Некрасов Д.В., Федорова О.И., Цедрик Т.П., Болтовский В.С. Влияние электромагнитного поля сверхвысоких частот на целлюлозу // Весці АН Беларусі. Серыя хімічных навук. 1995. №2. С. 57-61.

40. Базарнова Н.Г., Карпова Е.В., Катраков И.Б., Маркин В.И., Микушина И.В., Ольхов Ю.А., Худенко С.В. Методы исследования древесины и ее производных. Барнаул, 2002. 160 с.

41. Жбанков Р.Г. Инфракрасные спектры целлюлозы и ее производных. Минск, 1964. 338 с.

42. Капуцкий Ф.Н., Герт Е.В., Торгашов В.И., Зубец О.В. Гидрогели медицинского назначения, полученные путем окислительно-гидролитической модификации целлюлозы // Химические волокна. 2005. №6. С. 59-62.

43. Латош М.В., Алексеев А.Д., Резников В.М. Механизм процесса окисления древесины и ее компонентов перекисью водорода. 1. Превращения перекиси водорода при окислении древесины в щелочной среде // Химия древесины. 1980. №2. С. 38-42.

44. Brasileiro L.B., Colodette J.L., Piló-Veloso D. A utilização de perácidos na deslignificação e no branqueamento de polpas celulósicas // Química Nova. 2001. Vol. 24. N6. Pp. 819-829.

45. Jääskeläinen A.S., Tapanila T., Poppius-Levlin K. Carbohydrate reactions in peroxyacetic acid bleaching // Journal of Wood Chemistry and Technology. 2000. Vol. 20, N1. Pp. 43-59.

Поступило в редакичию 20 декабря 20132.

После переработки 4 марта 2014 г.

Kushnir E.J., Autlov S.A., Bazarnova N.G. PREPARATION OF MICROCRYSTALLINE CELLULOSE DIRECTLY FROM WOOD UNDER MICROWAVE IRRADIATION

Altai State University, pr. Lenina, 61, Barnaul, 656049 (Russia), e-mail: eugenekuschnier@ gmail.com

The influence of the composition of solutions of peracetic acid on a change the characteristics of cellulose during the oxidative-hydrolytic destruction of aspen and pine wood under microwave irradiation has been investigated. Samples of the prepared cellulose were characterized by means of viscometry, X-ray diffraction and IR spectroscopy. It was found that the main factor determining the rate of destruction of cellulose to low degree of polymerization values in acid medium at the initial concentration of peracetic acid not exceeding $15 \%$ and initial concentration of hydrogen peroxide no more than $3 \mathrm{~mol} \mathrm{dm}^{-3}$ is the concentration of sulfuric acid. The disordering effect of microwave irradiation on the crystallites of cellulose under its preparation from pine wood at the sulfuric acid concentration of $0.06 \mathrm{~mol} \mathrm{dm}^{-3}$ and increasing the duration of oxidative-hydrolytic treatment from 1 to $2 \mathrm{~h}$ has been revealed. It is shown that the characteristics of the products prepared from aspen and pine wood by oxidative-hydrolytic treatment with $15 \%$ peracetic acid under microwave irradiation at the process duration of $1.5-2 \mathrm{~h}$ and the sulfuric acid concentration of $0.3-0.7 \mathrm{~mol} \mathrm{dm}^{-3}$ correspond to partially oxidized microcrystalline cellulose.

Keywords: aspen wood, pine wood, peracetic acid, oxidative-hydrolytic destruction, microwave, microcrystalline cellulose.

\footnotetext{
* Corresponding author.
} 


\section{References}

1. Battista O.A., Smith P.A. Industrial and Engineering Chemistry, 1962, vol. 54, no. 9, pp. 20-29.

2. Patent 2978446 (US). 1961.

3. Patent 2313261 (CA). 1999.

4. Patent 4745058 (US). 1988.

5. de Oliveira R.L., Barud H.S., de Assunção R.M.N., Meireles C.S., Carvalho G.O., Filho R.G., Messaddeq Y., Ribeiro S.J.L. Journal of Thermal Analysis and Calorimetry, 2011, vol. 106, no. 3, pp. 703-709.

6. Patent 101914859 (CN). 2012. (in Chinese).

7. Patent 7005514 (US). 2006.

8. Patent 2377732 (CA). 2001.

9. Kazakova E.G., Demin V.A. Zhurnal prikladnoj himii, 2009, vol. 82, no. 3, pp. 502-505. (in Russ.).

10. Patent 4645541 (US). 1987.

11. Kocheva L.S., Karmanov A.P. Himija i tehnologija rastitel'nyh veshhestv: materialy II Vserossijskoj konferencii. [Chemistry and Technology of Plant Substances: Materials 2nd All-Russian Conference]. Kazan, 2002 , p. 140. (in Russ.).

12. Gaonkar S.M., Kulkarni P.R. Acta Polymerica, 1989, vol. 40, no. 4, pp. 292-293.

13. Ejikeme P.M. Cellulose, 2008, vol. 15, no. 1, pp. 141-147.

14. El-Sakhawy M., Hassan M.L. Carbohydrate Polymers, 2007, vol. 67, no. 1, pp. 1-10.

15. Mohamad Haafiz M.K., Eichhorn S.J., Hassan A., Jawaid M. Carbohydrate Polymers, 2013, vol. 93, no. 2, pp. 628-634.

16. Patent 102808347 (CN). 2012. (in Chinese).

17. Patent 101413016 (CN). 2009. (in Chinese).

18. Patent 5346589 (US). 1994.

19. Patent 6392034 (US). 2002.

20. Patent 3388119 (US). 1968.

21. Kuznecova S.A., Kuznecov B.N., Aleksandrova N.B., Danilov V.G., Zhizhaev A.M. Himija v interesah ustojchivogo razvitija, 2005, vol. 13, no. 2, pp. 261-269. (in Russ.).

22. Barmin M.I., Grebenkin A.N., Bojko A.I., Ivanova E.E., Kartavyh V.P., Kononeko V.P., Mel'nikov V.V. Izvestija vysshih uchebnyh zavedenij. Himija i himicheskaja tehnologija, 2004, vol. 47, no. 3, pp. 156-158. (in Russ.).

23. Sarymsakov A.A., Baltaeva M.M., Nabiev D.S., Rashidova S.Sh., Jugaj S.M. Himija rastitel'nogo syr'ja, 2004, no. 2, pp. 11-16. (in Russ.).

24. Patent 2137779 (RU). 1999. (in Russ.).

25. Kuznetsov B.N., Kuznetsova S.A., Danilov V.G., Yatsenkova O.V., Petrov A.V. Reaction Kinetics, Mechanisms and Catalysis, 2011, vol. 104, no. 2, pp. 337-343.

26. Danilov V.G., Jacenkova O.V., Grjazina E.F., Kuznecov B.N. Novye dostizhenija v himii $i$ himicheskoj tehnologii rastitel'nogo syr'ja: materialy V Vserossijskoj konferencii. [New Advances in Chemistry and Chemical Engineering Plant Materials: Materials 5th All-Russian Conference]. Barnaul, 2012, pp. 83-85. (in Russ.).

27. Vshivkova I.A., Karetnikova N.V., Pen R.Z., Byvshev A.V. Novye dostizhenija v himii i himicheskoj tehnologii rastitel'nogo syr'ja: materialy V Vserossijskoj konferencii. [New Advances in Chemistry and Chemical Engineering Plant Materials: Materials 5th All-Russian Conference]. Barnaul, 2012, pp. 79-80. (in Russ.).

28. Sharkov V.I., Kujbina N.I., Solov'eva Ju.P., Pavlova T.A. Kolichestvennyj himicheskij analiz rastitel'nogo syr'ja. [Quantitative Chemical Analysis of Plant Raw Materials]. Moscow, 1976, 72 p. (in Russ.).

29. Kushnir E.Ju., Autlov S.A., Bazarnova N.G. "Ma'nggilik el» — Qazaqstan bilimi men ghi'li'mi'n jangghi'rtwdi'ng wa'jdemesi» atti' "Amanjolov okwlari'-2014»: Hali'q. ghi'l.-ta'jir. konf. materi"aldari'ni'ng ji"naghi'. [Proceedings International Scientific-Practical Conference «Amanzholov Readings-2014» on the Theme «Mangilik Yel (the Eternal Land)» - Motivation for the Modernization of Education and Science of Kazakhstan»]. Ust-Kamenogorsk, 2014, part II, pp. 63-66. (in Russ.).

30. Jastrebinskij A.A. Metody issledovanija celjullozy. Pod red. V.P. Karlivana. [Methods of Investigation Cellulose. Ed. by V.P. Karlivan]. Riga, 1981, pp. 44-55. (in Russ.).

31. Poljak A. Holzforschung, 1951, vol. 5, no. 2, pp. 31-33. (in German).

32. Kushnir E.Ju., Autlov S.A. Trudy molodyh uchenyh Altajskogo gosudarstvennogo universiteta: materialy XXXVI nauchnoj konferencii. [Proceedings of Young Scientists of Altai State University : Materials $36^{\text {th }}$ Scientific Conference]. Barnaul, 2009, vol. 6. pp. 138-139. (in Russ.).

33. Kushnir E.Ju., Autlov S.A., Bazarnova N.G. Trudy molodyh uchenyh Altajskogo gosudarstvennogo universiteta: materialy XXXIX nauchnoj konferencii. [Proceedings of Young Scientists of Altai State University : Materials 39 ${ }^{\text {th }}$ Scientific Conference]. Barnaul, 2012. vol. 9. pp. 153-154. (in Russ.).

34. Gal'brajh L.S. Sorosovskij obrazovatel'nyj zhurnal, 1996, no. 11, pp. 47-53. (in Russ.).

35. Azarov V.I., Burov A.V., Obolenskaja A.V. Himija drevesiny $i$ sinteticheskih polimerov. [Wood Chemistry and Synthetic Polymers]. St. Petersburg, 1999, 628 p. (in Russ.).

36. Akim Je.L. Himija drevesiny, 1984, no. 4, pp. 3-17. (in Russ.).

37. Filipp B., Shtege H.-H. Himija drevesiny, 1976, no. 2, pp. 3-9. (in Russ.).

38. Petropavlovskij G.A., Kotel'nikova N.E. Himija drevesiny, 1979, no. 6, pp. 3-21. (in Russ.).

39. Nekrasov D.V., Fedorova O.I., Cedrik T.P., Boltovskij V.S. Vesci AN Belarusi. Seryja himichnyh navuk, 1995, no. 2, pp. 57-61. (in Russ.) 
40. Bazarnova N.G., Karpova E.V., Katrakov I.B., Markin V.I., Mikushina I.V., Ol'khov Iu.A., Khudenko S.V. Metody issledovanija drevesiny i ee proizvodnyh. [Methods of Investigation of Wood and Its Derivatives]. Barnaul, 2002, 160 p. (in Russ.).

41. Zhbankov R.G. Infrakrasnye spektry celljulozy i ee proizvodnyh. [Infrared Spectra of Cellulose and Its Derivatives]. Minsk, 1964, 338 p. (in Russ.).

42. Kapuckij F.N., Gert E.V., Torgashov V.I., Zubec O.V. Himicheskie volokna, 2005, vol. 6, pp. 59-62. (in Russ.).

43. Latosh M.V., Alekseev A.D., Reznikov V.M. Himija drevesiny, 1980, vol. 2, pp. 38-42. (in Russ.).

44. Brasileiro L.B., Colodette J.L., Piló-Veloso D. Química Nova, 2001, vol. 24, no. 6, pp. 819-829. (in Portuguese).

45. Jääskeläinen A.S., Tapanila T., Poppius-Levlin K. Journal of Wood Chemistry and Technology, 2000, vol. 20, no. 1, pp. 43-59.

Received December 20, 2013

Revised March 4, 2014 